\title{
Fluorine F 18 4-L-fluoroglutamine (2S,4R)
}

National Cancer Institute

\section{Source}

National Cancer Institute. Fluorine F18 4-L-fluoroglutamine (2S,4R). NCI Thesaurus.

Code C103196.

A radioconjug ate and glutamine analog consisting of the fluorine $F 18$ labeled 2S, 4R stereoisomer of 4-fluorog lutamine with potential use as a metabolic tracer for tumor imaging. Upon intravenous administration, fluorine F 18 4-L-fluorog lutamine $(2 S, 4 R)$ is preferentially taken up by cancer cells, possibly driven by c-Myc upregulation. Upon positron emission tomography (PET), cancer cells can be imaged. Tumor cells use the amino acid glutamine for nutritional purposes necessary for energy production and growth; as tumor cells proliferate more rapidly than normal healthy cells, glutamine uptake is higher in certain cancer cells. 